\title{
Hydrology of South Asia from the Perspective of Global Environmental Changes
}

Keshav P. Sharma

\begin{abstract}
On average, South Asian river basins drain about 2,672 $\mathrm{km}^{3}$ of water to the oceans every year, which is almost $6 \%$ of the global runoff. These rivers also contribute $15 \%$ to $20 \%$ of the global oceanward sediment flux. Retreating glaciers and decreasing flows during low flow seasons have already shown the signatures of global warming in the region. Temperature trends in the South Asian region range from $-2.9^{\circ} \mathrm{C}$ per decade to $+4.0^{\circ} \mathrm{C}$ per decade. Similarly, precipitation changes fall in the range of $-8 \%$ to $+18 \%$ during the period of available records. One of the major concerns regarding climatic change in the region is the tendency of decreasing low flows in several major river basins. Such alterations in river discharge may cause adverse impacts on available water supplies during critical periods. Besides, the region is subjected to high vulnerabilities of water resources because of population pressure, poverty and agriculture-based economy, strong temporal and spatial variation of precipitation, and significant spatial variations of geological parameters. The management of water resources needs to consider the integrated impacts of demographic, land-use, and climatic changes in an integrated manner.
\end{abstract}

Key words: South Asia, water resources, climate change, environmental change, precipitation

\section{Introduction}

South Asia, with four percent of the global landmass, Saccommodates almost one fourth population of the world. With average annual per capita income at US $\$ 500$, this is also the region shared by economically disadvantaged and educationally backward population. The region is one of the most vulnerable parts of the world to any significant climatic change primarily due to inadequate adaptive capacity, high annual variability of the monsoon climate and diverse physiographic and geological conditions. Depending on hydrological models used and regions considered, the expected increase of runoff in the scenario of doubled $\mathrm{CO}_{2}$ is expected to be as high as $30 \%$ in summer and decrease up to nine percent in winter (Houghton 2001; IPCC 1998; Sharma, Vorosmarty and Moore III 2000). These climatic changes may intensify the recurring floods and droughts in the region with severe impacts on economy.

Decrease in dry season flows is of particular concern as several parts of the region is already facing water-stress situation due to rapid population growth. Since less than $20 \%$ of the annual surface runoff is available during dry season periods, it is significant in terms of water availability and water resources utilization. Major South Asian cities with rapidly increasing population are already facing acute shortage of water. For instance, in

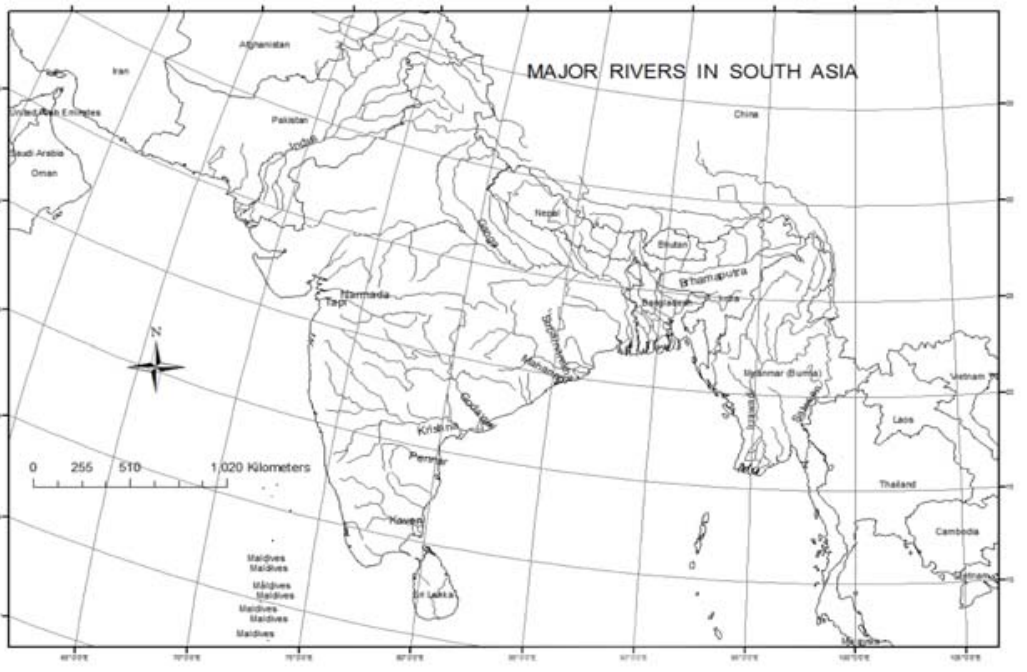
metropolitan cities like Chennai in India and Kathmandu in Nepal, demands of water for domestic use exceeds the supply by almost $40 \%$ on average (NWSC 2000; Shiklomanov and Shiklomanov 1999).

Retreating glaciers in the Himalayas (Vohra 1981) and submergence of highly populated seacoasts as a result of climate-induced sea level rise are additional hydrological problems in South Asia. An assessment of climate change impacts show that more than six million people in Bangladesh may be affected if there is one metre rise in sea level along the coastal areas of the Bay of Bengal (Houghton 2001).

\section{Study Area}

The South Asian river basins considered in this study (Figure 1) include the rivers draining from the Indian subcontinent to either the Arabian Sea or to the Bay of Bengal. Besides the South Indian and Sri Lankan rivers, the study area covers all the Himalayan rivers: the Indus, Ganga-Brahmaputra, Irrawady and Salween. Politically, the region includes the eastern part of Afghanistan drained by the Kabul river, Pakistan, India, Nepal, Bangladesh, Myanmar and Sri Lanka.
Figure 1. Major River Systems in the South Asian Region.

The study area includes the landmass experiencing mainly tropical or temperate climate. Some highlands of the Hindu Kush-Himalayan (HKH) region provide an environment for the varieties of climate and biodiversity within short spatial peripheries. The region is particularly diverse in terms of atmospheric and hydrologic elements. Northeast India receives the highest annual precipitation of the world, whereas, the west India has extensive deserts devoid of precipitation and water sources. Under the influence of the monsoons, the region receives $70 \%$ to $90 \%$ 
of annual precipitation during summer monsoons. Winter precipitation in the northern and western parts of the region is influenced by the western disturbances that bring moisture from the Mediterranean region.

Only about one-fourth of the region is covered by forest. Use of water for irrigation is the major component of water resources as the economy of the region is dominated by agricultural practices (IPCC 1998).

\section{Data}

The period of available data is not homogeneous in the region. The longest meteorological records available for several stations in India exceeds 100 years; whereas, data for Pakistan and Sri Lanka are available for the past 60 to 70 years. Maximum record lengths for the rest of the region are limited to about 50 years.

Since hydrological data are not freely available for most parts of the region, studies have to be relied on published literature. Data for the rivers in Myanmar are very scanty even in available literature. Compilation of available data and information, however, provide valuable information regarding climatic trends, hydrologic trends and utilisation of water resources.

\section{Water Resources}

The rivers draining the Indian sub-continent are some of the largest rivers in the world. For instance, the Brahmaputra, Ganges, Irrawady, Godavari, Krishna and Salween rank at 4th, 5th, 12th, 29th, 39th and 44th respectively, among the global river systems in terms of annual discharge (Leeden, Troise and Todd 1990 ). A list of the major rivers of South Asia and the annual water flux towards ocean (excluding reservoir impacts) are presented in Table 1.

\begin{tabular}{|l|r|r|}
\hline River Basin & Drainage Area $\mathbf{~ ( k m ~}^{\mathbf{2}}$ ) & Discharge (million $\mathbf{~}^{\mathbf{3}}$ ) \\
\hline Indus & 941,000 & 200,000 \\
\hline Ganga & $1,100,000$ & 590,000 \\
\hline Brahmaputra & 935,000 & 624,000 \\
\hline Meghna & 80,000 & 100,000 \\
\hline Godavari & 298,000 & 113,000 \\
\hline Krishna & 308,000 & 61,500 \\
\hline Irrawadi & 430,000 & 429,000 \\
\hline Salween & 280,000 & 47,000 \\
\hline Narmada & 98,800 & 40,700 \\
\hline Tapi & 65,100 & 18,000 \\
\hline Subarnarekha & 19,300 & 7,940 \\
\hline Brahmani & 39,000 & 18,300 \\
\hline Mahanadi & 142,000 & 66,600 \\
\hline Pennar & 55,000 & 3,240 \\
\hline Cauvery & 87,900 & 21,000 \\
\hline Medium \& Small & 446,000 & 280,000 \\
\hline Basins in India & & 51300 \\
\hline Sri Lanka & 65500 & 0 \\
\hline Desert & 100,000 & $\mathbf{2 , 6 7 1 , 5 8 0}$ \\
\hline Total & $\mathbf{5 , 4 9 0 , 6 0 0}$ & \\
\hline
\end{tabular}

Table 1. Major River Basins in South Asia (based on Leeden, Troise and Todd 1990; Rao 1975; Ranatunga 1985; Subba 2001).
Table 1 shows that the South Asian basins, occupying $4 \%$ of the global land surface area contributing almost $6 \%$ of the global runoff, flux towards the oceans. The region occupies $13 \%$ of the Asian landmass. Table 2 presents the country wise distribution of river basins draining towards the Arabian Sea or the Bay of Bengal.

\begin{tabular}{|l|c|l|}
\hline \multicolumn{1}{|c|}{ Country } & Drainage Area $\mathbf{( k m}^{\mathbf{2}} \mathbf{~}$ & \multicolumn{1}{|c|}{ Remarks } \\
\hline Afghanistan & 75000 & Kabul River \\
\hline China & 480,000 & $\begin{array}{l}\text { Headwater of Indus, } \\
\text { Ganga-Brahmaputra and } \\
\text { Salween }\end{array}$ \\
\hline Pakistan & 796,000 & \\
\hline India & $3,290,000$ & \\
\hline Nepal & 147,000 & \\
\hline Bhutan & 46,500 & \\
\hline Bangladesh & 148,000 & \\
\hline Myanmar & 677,000 & \\
\hline Sri Lanka & 65,600 & \\
\hline Thailand & 25,000 & A tributary to Salween \\
\hline Total & $\mathbf{5 , 7 5 0 , 0 0 0}$ & \\
\hline
\end{tabular}

Table 2. Country wise Distribution of the River Basins Draining to the Arabian Sea or the Bay of Bengal.

\section{Water Availability}

Since population density is a major factor influencing the per capita availability of water, water availability is diverse within the region. Per capita availability of water is relatively high in the high mountainous areas of the Himalayan region and the Tibetan Plateau. On the other hand, despite receiving water from large basins, water availability in the low lying valleys and flood plains is low. Thelow-lands, such as the Indus, Ganges, and Brahmaputra plains are some of the most densely populated areas of the world. Table 3 presents the country wise availability of surface water without considering upstream allocations.

\begin{tabular}{|l|r|r|r|}
\hline \multirow{2}{*}{ Country } & $\begin{array}{c}\text { Population } \\
\text { (2010) }\end{array}$ & $\begin{array}{c}\text { Water availability } \\
\text { (Stream flows) }\end{array}$ & $\begin{array}{c}\text { Per Capita } \\
\text { Water Availability }\end{array}$ \\
\cline { 2 - 4 } & Million & Million $\mathbf{~}^{\mathbf{3}}$ & $\mathbf{m}^{\mathbf{3}} /$ year \\
\hline Afganistan & 30.6 & 65,000 & 2,124 \\
\hline Pakistan & 173.4 & 200,000 & 1,153 \\
\hline India & 1170.9 & $2,015,000$ & 1,721 \\
\hline Nepal & 29.9 & 215,000 & 7,191 \\
\hline Bhutan & 2.3 & 65,000 & 28,261 \\
\hline Bangladesh & 164.4 & $1,314,000$ & 7,993 \\
\hline Myanmar & 55.4 & 476,000 & 8,592 \\
\hline Sri Lanka & 20.5 & 51,300 & 2,502 \\
\hline South Asia & $\mathbf{1 , 6 4 7 . 4}$ & $\mathbf{4 , 4 0 1 , 3 0 0}$ & $\mathbf{2 , 6 7 2}$ \\
\hline
\end{tabular}

Table 3. Country wise Availability of Surface Water in the South Asian Countries without Upstream Allocation (based on UNDP 2003, World Bank 2011, Green Facts 2011).

The per capita water availability (Table 3) can be misleading in the countries of the monsoon region where most of the flows occur during summer monsoons. It is 
estimated that the usable water is high for the Indus at $62 \%$; however, it can be as low as $4 \%$ for the Brahmaputra owing to different reasons including monsoonal pattern of river flows (Subba 2001). A study made by the National Commission on Integrated Water Resources Development indicates that only one-third of the available water resources are utilizable in India (Ramasastri 2004).

According to the Falkenmark and Lindh (1976), a country is considered to be under water stress when the available freshwater falls below $1,700 \mathrm{~m}^{3}$ per person per year. Under these criteria, the country is considered to be under water shortage if the available freshwater falls below $1,000 \mathrm{~m}^{3}$ per person per year. Although the region as a whole can be considered water-rich in term of Falkenmark criteria, the availability varies significantly from one region to another. Pakistan, the third largest country in South Asia, is already under water stress conditions.

\section{Snow and Glaciers}

One of the most sensitive areas of the South Asian region is the high elevation area in the $\mathrm{HKH}$ region. Snow and glaciers are not only the most sensitive physical features to climatic changes but also an indicator of such changes. Changes in snow and glacier area may also contribute to the creation of additional source for greenhouse gases. Since the snowline in the Himalayan region lies close to the 5,000 meter level, the snow and glaciers are sensitive above this elevation.

Vohra (1981) estimates $1,400 \mathrm{~km}^{3}$ of snow and glaciers in the $\mathrm{HKH}$ region. A recent inventory of glacial lakes developed by the United Nations Environment Program (UNEP) and the International Centre for the Integrated Mountain Development (ICIMOD) shows that Nepal alone houses 2,323 glacial lakes covering an area of $76 \mathrm{~km}^{2}$ (Mool, Bajracharya and Joshi 2001). Additional inventory compiled by ICIMOD (2011) that includes major parts of Indian Himalayas, Indus basin of Pakistan, Bhutan and Nepal indicates that the $\mathrm{HKH}$ region accommodates more than 15,000 glaciers and more than 8,800 glacial lakes.

The trends of increasing temperatures in high elevation areas of the Himalayas are found to be more significant than the trends in the adjoining plains (Sharma 2010; Shrestha, Wake et al 1999). Because of the warming effects, several glaciers in the Hindu Kush-Himalayan region are found to be retreating at higher rates in the recent past (Vohra 1981; Wake and Mayewski 1996). Such retreats have been responsible for the formation of several glacial lakes some of which have naturally burst as disastrous floods called Glacial Lake Outburst Floods (GLOFs) causing extensive damage in downstream valleys. A study has identified 20 potentially dangerous glacial lakes, which are developing at an alarming rate induced by the increasing trends of temperature (Mool, Bajracharya and Joshi 2001). An updated study by ICIMOD (2011) has further confirmed the potential dangers posed by 17 glacial lakes identified before in addition to five newly identified potentially dangerous glacial lakes.

\section{Sediment}

South Asia contributes $15 \%$ to $20 \%$ of the global ocean ward sediment flux (Sharma 1999). Impact of climatic changes on sediment transport is an important component in the assessment of water resources of the region. Erosion of fertile soil and the deposition of sediment in reservoirs and agricultural lands are typical problems faced by the communities involved in the utilisation of water resources. Erosion is directly proportional to rainfall intensity and sediment transport on a river is directly proportional to river discharges and stream flow velocities. Hence, sediment transport is directly influenced by changes either in precipitation pattern or in stream flow pattern. The major human impacts on the sediment delivery pattern have been the construction of reservoirs in the region (Sharma 2005).

Regular monitoring of sediment transport in the region is limited compared to the monitoring of other hydrometeorological variables. Based on the data available in several reports and other publications, Sharma (2001) provides statistical models, which indicate significant nonlinear rise in sediment transport rates when precipitation increases by more than 20\% of its normal values. Table 4 and Table 5 present an assessment of the sediment flux from the South Asian region with respect to the river basins and nations respectively.

\begin{tabular}{|c|c|c|c|}
\hline River & Area $\left(\mathrm{km}^{2}\right)$ & $\begin{array}{l}\text { Sediment Flux } \\
\text { (Million Tons) }\end{array}$ & References \\
\hline \multicolumn{4}{|l|}{ Bay of Bengal } \\
\hline $\begin{array}{l}\text { Ganga- } \\
\text { Brahmaputra }\end{array}$ & $1,648,000$ & 1,100 & $\begin{array}{l}\text { Ludwig, Probst and } \\
\text { Kempe } 1996\end{array}$ \\
\hline Damodar & 20,000 & 28 & $\begin{array}{l}\text { Milliman and Syvitski } \\
1992\end{array}$ \\
\hline Mahanadi & 132,000 & 68 & WRI 1992-1993 \\
\hline Godavari & 310,000 & 170 & $\begin{array}{l}\text { Biksham and } \\
\text { Subramanian } 1988\end{array}$ \\
\hline Krishna & 250,000 & 64 & $\begin{array}{l}\text { Milliman and } \\
\text { Syvitski1992 }\end{array}$ \\
\hline Pennar & 48,700 & 7 & $\begin{array}{l}\text { Vaithiyanathan, } \\
\text { Ramanathan et al } \\
1988\end{array}$ \\
\hline Cauvery & 87,900 & 32 & $\begin{array}{l}\text { Narayana and Ram } \\
\text { Babu } 1983\end{array}$ \\
\hline Irrawadi & 419,000 & 260 & $\begin{array}{l}\text { Ludwig, Probst and } \\
\text { Kempe } 1996\end{array}$ \\
\hline Salween & 325,000 & 168 & Sharma 2003 \\
\hline Other rivers & 734,000 & 360 & Sharma 2003 \\
\hline Total & $3,959,600$ & 2,257 & \\
\hline \multicolumn{4}{|l|}{ Arabian Sea } \\
\hline Indus & 958,000 & 481 & WRI 1992-1993 \\
\hline Mahi & 37,600 & 22 & $\begin{array}{l}\text { Narayana and Ram } \\
\text { Babu } 1983\end{array}$ \\
\hline Narmada & 98,800 & 61 & $\begin{array}{l}\text { Narayana and Ram } \\
\text { Babu } 1983\end{array}$ \\
\hline Tapi & 66,900 & 100 & $\begin{array}{l}\text { Narayana and Ram } \\
\text { Babu } 1983\end{array}$ \\
\hline $\begin{array}{l}\text { Other west } \\
\text { flowing } \\
\text { rivers }\end{array}$ & 580,700 & 278 & Sharma 2003 \\
\hline Islands & 65,000 & 35 & Sharma 2003 \\
\hline Total & $1,807,000$ & 976 & \\
\hline Grand Total & & 3,233 & \\
\hline
\end{tabular}

Table 4. Sediment Flux from the South Asian Rivers towards Ocean. 


\begin{tabular}{|c|c|c|}
\hline Country & $\begin{array}{c}\text { Sediment Flux } \\
\text { towards ocean } \\
\left(10^{6} \text { tons }\right)\end{array}$ & References \\
\hline Pakistan & 481 & Ahmad and Chaudhary 1988 \\
\hline India & 990 & Sharma 2003 \\
\hline Bangladesh & 1100 & Ludwig, Probst, Kempe 1996 \\
\hline Myanmar & 524 & Sharma 2003 \\
\hline Sri Lanka & 35 & Sharma 2003 \\
\hline Total & 3236 & \\
\hline
\end{tabular}

Table 5. Sediment flux from the South Asian countries towards Ocean.

\section{Climatic Changes in South Asia}

South Asia, considered in this study, falls under two climatic divisions as classified in the regional impact studies of IPCC (1998): the tropical Asia and the Middle East and Arid Asia. Cruz, Harasawa et al (2007) report changes in temperature in the region ranging from negligible up to $1^{\circ} \mathrm{C}$ in the past 100 years. The precipitation trends for the same period have been almost non-discernible.

The model based projected climate change in the region ranges the rise in temperature from $1^{\circ} \mathrm{C}$ to $5.44^{\circ} \mathrm{C}$ in winter by 2099. Depending on a model, precipitation is expected to increase by $-16 \%$ in winter to $31 \%$ during wet seasons with higher uncertainties during dry seasons (Cruz, Harasawa et al 2007).

Different country-level studies in South Asia show changes in temperature ranging from $-2.9^{\circ} \mathrm{C}$ to $4.0^{\circ} \mathrm{C}$ per decade. Decreasing trends of temperature are found primarily in a few locations in Pakistan and the western part of India. The rest of the region is primarily dominated by rising trends of temperature. Variable length of records used in the studies for different sub-regions, however, makes the comparison difficult for computing trends using temporally homogeneous information.

Average rise of temperature in India, based on the records of 73 stations from 1901 to 1982, is estimated at $0.4^{\circ} \mathrm{C}$ (Kumar, Kumar et al 2002), which is close to the global averages reported in the Third Assessment Report of the Intergovernmental Panel on Climate Change (IPCC 2001). The 100 year rise of temperature in India, reported by Cruz, Harasawa et al (2007), is $0.5^{\circ} \mathrm{C}$. Bangladesh reports the changes in maximum temperature in the range of $-0.29^{\circ} \mathrm{C} /$ decade to $1^{\circ} \mathrm{C} /$ decade (Choudhury, Quadir et al 2003; Cruz, Harasawa et al 2007). The computed trends in Pakistan range from slight decrease to temperature increase up to $1^{\circ} \mathrm{C}$ between the 30 year normal values before and after 1960 (Ahmad, Bari and Muhammed 2003). Using the period as in Pakistan the temperature changes in Sri Lanka are estimated in the range of $0.1^{\circ} \mathrm{C}$ to $0.36^{\circ} \mathrm{C}$ per decade (Somasekaram, Perera et al 1997).

\section{Conclusion and Recommendations}

South Asia experiences the most impressive impacts of monsoon cycle with extreme annual variability of climatic conditions. Summer monsoon supports the region with one of the most densely populated areas of the world bringing moisture from the Arabian Sea and the Bay of Bengal. The region is highly vulnerable to climatic changes particularly because of variability in climatic conditions, dense population and inadequate adaptive capacities. Water is one of the most vulnerable elements providing lifeline to the population, agriculture, bio-diversity and development activities, such as industries. Impact of climatic changes on water induced disasters in the region is an additional aspect of concern.

Records from the region have already shown trends in climatic and hydrological variables. South Asia has been experiencing the trends of rising temperature except at a few locations in the western end of the study area. Temperature trends in the South Asian region ranges from $-0.29^{\circ} \mathrm{C}$ per decade to $0.4^{\circ} \mathrm{C}$ per decade.

One of the major concerns regarding climatic changes in the region is the tendency of decreasing low flows in several major river basins. Such alterations in river discharges may cause adverse impacts on the available water supplies during critical periods. Besides, the region is subjected to high vulnerabilities of water resources because of population pressure, poverty, agriculturebased economy, strong temporal and spatial variation of precipitation and significant spatial variations of geological parameters. Management of water resources considering the integrated impacts of demographic and climatic changes is one of the greatest challenges in the region.

The general picture of water resources in relation to climatic changes in the region highlights the urgency of detailed studies required in the region. A major challenge for such studies is the compilation and assessment of available hydrological and meteorological information. Available information is highly scattered in terms of spatial and temporal sampling requiring gap-filling exercises. Development of proxy information using indirect and nontraditional approaches needs to be explored.

Availability of groundwater and its relation with the climate and surface water resources is another area that needs further exploration. Most of the urban centres in the region are highly dependent on groundwater resources for daily water use. Similarly, groundwater is the major source of irrigation in the fertile flood plains in the region.

Keshav Prasad Sharma, $P h D$, is the Director General of the Department of Hydrology and Meteorology (DHM), Ministry of Environment, Government of Nepal. Dr. Sharma graduated from the Tribhuvan University, Kathmandu, Nepal. He obtained an M.Tech in hydrology from the University of Roorkee, India and a PhD in Earth Sciences from the University of New Hampshire, USA. He has served DHM as a meteorologist since 1979 and as a hydrologist since 1982. Dr. Sharma has published about 5 o papers in national and international scientific journals and proceedings.

Corresponding address: $k \_p \_s h a r m a @ h o t m a i l . c o m$

\section{References}

Ahmad, N. and R.G. Chaudhary, 1988, Irrigated Agriculture of Pakistan, Lahore: Shahzad Nazir.

Ahmad, S., A. Bari and A. Muhammed, 2003, 'Climate change and water resources of Pakistan: impact, vulnerabilities, coping mechanisms', pp.138-200 in A. Muhammed (ed.), Climate Change and Water Resources in South Asia, Kathmandu: Asianics Agro Dev International.

Biksham, G. and V. Subramanian, 1988, 'Sediment transport of the Godavari basin and its controlling factors', Journal of Hydrology 101:275-290. 
Choudhury, A.M., D.A. Quadir, S. Neelormi and A.U. Ahmed, 2003, 'Climate change and its impact on water resources of Bangladesh', pp.21-6o in A. Muhammed (ed.), Climate Change and Water Resources in South Asia, Kathmandu: Asianics Agro Dev International.

Cruz, R.V., H. Harasawa, M. Lal, S. Wu, Y. Anokhin, B. Punsalmaa, Y. Honda, M. Jafari, C. Li and N. Huu Ninh, 2007, 'Asia climate change 2007: Impacts, adaptation and vulnerability', pp.459-506 in M. L. Parry, O.F. Canziani, et al (eds.), Fourth Assessment Report of the Intergovernmental Panel on Climate Change, Cambridge, UK: Cambridge University Press.

Falkenmark, M., G. Lindh, 1976, Water for Starving World, Boulder, CO: Westview Press

Green Facts, 2011, 'Water availability information'; URL: http://www.greenfacts.org/en/water-resources.

Houghton, 2001, Global Warming: The Complete Briefing, Cambridge, UK: Cambridge University Press.

ICIMOD, 2011, Glacial Lakes and Glacial Lake Outburst Floods in Nepal, Kathmandu: International Center for Integrated Mountain Development.

IPCC (Intergovernmental Panel on Climate Change), 1998, The Regional Impacts of Climate Change: An Assessment of Vulnerability, Cambridge, UK: Cambridge University Press.

IPCC (Intergovernmental Panel on Climate Change), 2001, Scientific Basis: Summary for the Policy Makers, Cambridge, UK: Cambridge University Press.

Kumar, K.R., K.K. Kumar, R.G. Ashrit, S.K. Patawardhan and G.B. Pant, 2002, 'Climate change in India: Observations and model projections', pp.24-75 in P.R. Shukla, S.K. Sharma and P.V. Ramana (eds.), Climate Change and India: Issues, Concerns and Opportunities, New Delhi: Tata McGraw-Hill Publishing Co. Ltd.

Leeden, F. v.d., F.L. Troise and D.K. Todd, 1990, The Water Encyclopedia (2nd ed.), Boca Raton: Lewis Publishers.

Ludwig, W., J.-L. Probst and S. Kempe, 1996, 'Predicting the oceanic input of organic carbon by continental erosion', Global Biogeochemical Cycles 10(1):23-41.

Milliman, J.D. and J.P.M. Syvitski, 1992, 'Geomorphic/ tectonic control of sediment discharge to the ocean: The importance of small mountainous rivers', The Journal of Geology 100:525-544.

Mool, P.K., S.R. Bajracharya and S.P. Joshi, 2001, Inventory of Glaciers, Glacial Lakes and Glacial Lake Outburst Floods: Monitoring and Early Warning Systems in the Hindu Kush-Himalayan Region-Nepal, Kathmandu: International Center for Integrated Mountain Development.

Narayana, D.V.V. and Ram Babu, 1983, 'Estimation of soil erosion in India', Journal of Irrigation and Drainage Engineering 109(4):419-434.

NWSC, 2000, Annual Report, Kathmandu: Nepal Water Supply Corporation.

Ramasastri, K.S., 2004, 'Water resources management for sustainable development', pp.247-256 in $H$. Chandrasekharan, R. K. Sharma and K.V. Sundaram (eds.), Water Resources Development and Management, New Delhi: Mittal Publication.

Ranatunga, D.G.L., 1985, 'Surface water resources', pp.95115 in C.N. Maddumabandara and N. M. G. Navaratne (eds.), Some Aspects of Water Resources of Sri Lanka, Colombo, Sri Lanka: Irrigation Department.

Rao, K.L., 1975, India's Water Wealth: Its Assessment, Uses and Projections, New Delhi: Orient Longman.
Sharma, K.P., 1999, 'Regional sediment delivery pattern of the south Asian river basins to the coastal areas', pp.111-117 in J. Ratnasiri (ed.), South Asia Regional Workshop on Estuarine Modelling and Coastal Zone Management, Colombo, Sri Lanka: Ministry of Forestry and Environment.

Sharma, K.P., 2001, 'Global change impact on sediment flux in a Himalayan basin', pp.109-116 in Workshop on Global Change and Himalayan Mountains, Kathmandu: Institute for Development and Innovation.

Sharma, K.P., 2003, 'Sediment fluxes to coastal zone in South Asia and their relationship to human activities', pp.147-59 in J. Ratnasiri (ed.), South Asia Regional Workshop on Assessment of Material Fluxes to the Coastal Zone in South Asia and Their Impacts, Colombo, Sri Lanka: National Committee of International Geosphere Biosphere Program (IGBP).

Sharma, K.P., 2005, 'Impacts of human activities on regionwise budget and oceanward flux of sediment in South Asia', pp.132-133 in LOICZ II Inaugural Open Science Meeting, Egmond aan Zee, The Netherlands: Land Ocean Interactions in Coastal Zone (LOICZ).

Sharma, K.P., 2010, Climate Change Trends and Instances of Socio-Economic Effects in Nepal, Kathmandu: Jalsrot Vikas Sanstha.

Sharma, K.P., C. J. Vorosmarty and B. M. III, 2000, 'Sensitivity of the Himalayan hydrology to land-use and climatic changes', Climatic Change 47: 117-139.

Shiklomanov, I.A. and A.I. Shiklomanov, 1999, 'Assessment of the impacts of climate variability and change on the hydrology of Asia and Australia', pp.85-106 in J.C. van Dam (ed.), Impacts of Climate Change and Climate Variability on Hydrological Regimes, Cambridge, UK: Cambridge University Press.

Shrestha, A.B., C. Wake, P.A. Mayewski and J.E. Dibb, 1999, 'Maximum temperature trends in the Himalaya and its vicinity: an analysis based on temperature records from Nepal for the period 1971-94', Journal of Climate 12: 2775-2789.

Somasekaram, T., M.P. Perera, M.B.G. d. Silva and H. Gedellawatta (eds.), 1997, Arjuna's Atlas of Sri Lanka, Dehiwala, Sri Lanka: Arjuna Consulting Co. Ltd.

Subba, B., 2001, Himalayan Waters, Kathmandu: Panos South Asia.

UNDP, 2003, Human Development Report 2003, New York: United Nations Development Program, Human Development Report Office.

Vaithiyanathan, P., A. Ramanathan and V. Subramanian, 1988, 'Erosion, transport and deposition of sediment by the tropical rivers of India', pp.561-574 in M.P. Bordas and D.E. Walling (eds.), Sediment Budgets, Porto Alegre: IAHS Publication No.174.

Vohra, C.P., 1981, 'Himalayan glaciers', pp.138-151 in J.S. Lall (ed.), The Himalaya: Aspects of Change. New Delhi: Oxford University Press.

Wake, C.P. and P.A. Mayewski, 1996, Himalayan Interdisciplinary Paleoclimate Project: Science and Implementation Plan (Series 96-1), Durham, NH: Institute for the Study of Earth, Oceans and Space, University of New Hampshire, USA.

World Bank, 2011, Countries and Economies; url: data. worldbank.org/country.

WRI, 1992-1993, World Resources 1992-93: Guide to Global Environment, Washington: World Resources Institute. 